$\mathrm{BFJ}$

124,13

66

Received 1 May 2021

Revised 30 September 2021 17 November 2021

Accepted 19 November 2021

\title{
The impact of front-of-the- packaging nutrition labelling warnings on consumer habits: a scoping review exploring the case of the Chilean Food Law
}

\author{
Cintia Pereira da Silva
}

Department of Nutrition, School of Public Health, University of São Paulo, São Paulo, Brazil and

Food and Health Assessoria, Teresina, Brazil

Aline Cristina Bento

Instituto Racine, São Paulo, Brazil, and

Elaine Guaraldo

Health Division, Vigna Brasil Consultoria Em Assuntos Estratégicos e Regulatórios, São Paulo, Brazil and

Nutrição, Universidade Municipal de Sao Caetano do Sul, Sao Caetano do Sul, Brazil

\begin{abstract}
Purpose - The purpose of this scoping review was to summarise the general results of the Chilean Food Law implementation to help to understand how this policy has changed consumer's behaviour.

Design/methodology/approach - Preferred Reporting Items for Systematic Reviews and Meta-Analyses (PRISMA) extension for scoping reviews (PRISMA-ScR) guidelines were followed. Five databases were searched for studies published from January 2015 to February 2020 evaluating the Chilean population's perception, behaviour and purchasing habits of processed foods.

Findings - The results showed that consumers support the implementation of a front-of-package warning label (FOPWL) and thought it a good strategy to help make healthier food choices for themselves. However, even with a positive perception about these products, the intention-to-change the purchase of unhealthy food occurred only for sugar-sweetened beverages. Meanwhile, children did not stop eating foods that had a FOPWL, although the mothers' perception was that the presence of FOPWLs could be important to differentiate unhealthy from healthy products. The availability of products with FOPWLs at schools decreased, indicating that the law was being complied with and that the child-directed marketing strategy showed a reduction after the first phase of implementation.

Practical implications - This evidence will guide other countries about in understanding and improving this policy.
\end{abstract}

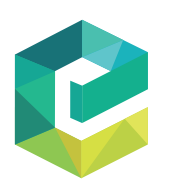

British Food Journal Vol. 124 No. 13,2022 pp. $66-80$ Emerald Publishing Limited 0007-070X

DOI 10.1108/BFJ-05-2021-0463 (c) Cintia Pereira da Silva, Aline Cristina Bento and Elaine Guaraldo. Published by Emerald Publishing Limited. This article is published under the Creative Commons Attribution (CC BY 4.0) licence. Anyone may reproduce, distribute, translate and create derivative works of this article (for both commercial and non-commercial purposes), subject to full attribution to the original publication and authors. The full terms of this licence may be seen at http://creativecommons.org/licences/by/4.0/legalcode

Funding: This research was funded by ALAIAB, Alianza Latinoamericana de Asociaciones de la Industria de Alimentos y Bebidas.

The authors declare no conflict of interest. The funders had no role in the design of the study, in the collection, analyses, interpretation of data and in the writing of the manuscript. 
Originality/value - This is the first study to gather research available in international databases that evaluated the results of the Chilean Law on the advertising of children's food and the perception, purchase intention, reformulation of products and consumption behaviour of the Chilean population.

Keywords Front-of-package, Chilean Food Law, Consumer behaviour, Nutrition labelling Paper type General review

\section{Introduction}

Obesity is a global public health concern, and its prevalence is increasing in low- and middleincome countries as well as in high-income countries. The main risk factors associated with obesity include socioeconomic, sociodemographic, behaviour and genetic aspects, which vary across nations and interact in a complex and multidimensional manner. To develop with effective prevention strategies for obesity, all nations must take this complexity into account (Endalifer and Diress, 2020).

Foods rich in substances such as saturated fats, sodium and sugars are often classified as unhealthy since their excessive intake has shown an association with increasing levels of noncommunicable diseases and weight gain over time (Pagliai et al., 2021).

Nutritional labelling normally shown in the back part of the food package is wellestablished worldwide. However, the adoption of front-of-package nutritional labelling (FOPNL), outlining the content of critical nutrients, has been recently encouraged as a public policy to help prevent and control obesity and related diseases (Storcksdieck Genannt Bonsmann et al., 2020; FAO, 2016).

Around the world, different models of FOPNL exist that can be mandatory or voluntary. Furthermore, they can be classified as interpretative, semi-interpretative and noninterpretative, varying in their graphical presentation (colours, formats and sizes), types of emphasised nutrients (critical or positive claims) and statement basis (in portion or $100 \mathrm{~g} / \mathrm{ml}$ ) (Kanter et al., 2018). Interpretative FOPNL models combine several criteria to establish an indication of the healthiness level of the food. They provide a judgement, opinion or guidance regarding the food without specific information about nutrients. Meanwhile, semiinterpretive models provide information about a set of specific nutrients. They use symbols, qualitative descriptors or colours to assist the consumer in understanding the level of each nutrient in food. Non-interpretive models present quantitative information about specific nutrients, without any kind of judgement, opinion, orientation or qualitative elements to assist in the interpretation of information. An FOPNL policy typically presents two main objectives: (1) to provide additional information to promote healthier food choices and (2) to stimulate the reformulation of food products towards healthier options by the industry (ANVISA, 2018).

Consumers consider certain foods healthy and others unhealthy. "Perceived healthiness" is a consumer's expectation of a product's influence on his or her state of health. Thus, it is important to know how they make this distinction. Plasek et al. (2020) showed that in food industry products six separate categories can influence consumers in their perception of the healthiness of food items: communicated information such as FOP (front-of-package) labels and health claims, product category, shape and colour of the product packaging, ingredients of the product, organic origin of the product, and taste and other sensory features of the product.

Talati et al. (2019) conducted an electronic survey to evaluate the consumer perception of five types of FOPNL currently in use around the world. Participants from 12 countries evaluated the same products, first without FOPNL and later with the following models on their labels: (1) Reference intake: indicates the amounts of essential nutrients present in the food and their percentage contributions based on the recommended daily intake for an adult; (2) Multiple traffic lights: in addition to informing the amounts of nutrients and the corresponding percentage based on the recommended daily intake, it uses colours to indicate
The impact of Chilean Food Law implementation 
BFJ

124,13

the healthiness of the food; (3) FOPWL: black hexagon with the text "high in" followed by saturated fat, salt, sugar or calories when a predetermined threshold is exceeded; (4) NutriScore: indicator that gives the food a health rating from A to E and is colour-coded; (5) Health star rating: hybrid model which associate a summary health indicator and displays nutrientspecific information next to the indicator. The survey participants elected the FOPWL as the easiest to be interpreted, however, according to them, it does not provide sufficient information and are less reliable and desired as mandatory.

Likewise, Taillie et al. (2020a, b) conducted a scoping review of 22 studies investigating how FOPNL affects consumer behaviour. The authors concluded that FOPWL was visually understood by consumers, easy to understand, assisted consumers in identifying products rich in nutrients of concern and discouraged them from purchasing those products. Other labelling systems, such as traffic light labels or Nutri-Score, were perceived as containing more information and had better performance in assisting the consumers classifying the healthiness of the products.

Data from a recent review of FOPNL strategies in the European Union indicate that more studies are required to better investigate a causal connection between the presence of FOPNL and changes in product formulations. Additionally, the review raised concerns that detected product reformulation or innovation is often limited to the FOP critical nutrients, reducing the incentive to improve other food components such as fibre, minerals and vitamins that could enhance the nutritional composition (Storcksdieck Genannt Bonsmann et al., 2020).

Countries around the world use interpretative labels on packaged foods and drinks in mandatory or voluntary ways. Nonetheless, the adoption of mandatory FOPWL has occurred mainly in Latin American countries. Peru, Uruguay and Mexico, which already have their strategies approved by governmental agencies, have laws that came into effect in June 2019, October 2020 and February 2021, respectively (MINSA, 2019; MINSAL, 2018; COFEPRIS, 2020). Brazil and Colombia, which recently had their strategies approved, plan to start their implementation in October 2022 and December 2022, respectively (ANVISA, 2020; MINSALUD, 2021).

In 1993, Finland was the first country to introduce FOPWL for excessive sodium content in some food products. Meanwhile, Chilean law was unprecedented in its scope making Chile the first country in the world to adopt mandatory FOPWL, and its experience will guide other countries about how to improve this policy. Since obesity is also a public health concern in Chile according to the latest studies $23 \%$ of school-age children and adolescents and $31.2 \%$ of adults present some degree of obesity in that country FOPWL may represent an important tool against this health issue (MINSAL, 2019; MINSAL, 2017).

According to the Chilean Ministry of Health (MINSAL), law no. 20.606/2012 has three main pillars. First, it provides the consumer with clear and understandable information using the FOPWL "High in" in the front part of the label, indicating that the food contains sodium, saturated fats and sugars at amounts that are higher than the limits established for such nutrients or calories. Second, it guarantees the provision of healthy food in schools by prohibiting the sale, promotion and/or free delivery of food containing FOPWL. Third, it protects children under 14 years of age from overexposure to food exceeding the determined limits of harmful nutrients (Kanter et al., 2018; MINSAL, 2019).

The Chilean Food Law was applied in three stages: the first occurred in June 2016, the second occurred in June 2018 and the third occurred in June 2019. Nutrient cut-off points become increasingly stricter over the three stages (MINSAL, 2019; Corvalán et al., 2018; Reyes et al., 2019).

The Chileans chose their warning model after conducting a study that included a review of the literature, qualitative evaluation (survey with mothers and adolescents with little knowledge of the subject and with a group of specialists), graphic design phase and 
quantitative analysis (with questionnaires at points of sale). A black-and-white octagon presenting a simple text indicating "high in <nutrient>" was chosen as the official FOPWL because it presented the best visualisation, comprehension and stimulus to change the intended purchase output according to the investigation. When packaged foods and beverages exceed the established limits for sugar, sodium, saturated fat and calories, one or more specific octagons of the same colour and size for each nutrient and/or caloric value must be placed on the front side of the label (Corvalán et al., 2018; Reyes et al., 2019). Figure 1 shows the official FOPWL of Chile.

Chilean health authorities believe that educating consumers regarding the choice of food products with fewer octagons will reduce the risks associated with obesity by changing the population's dietary habits in the medium and long term (Taillie et al., 2020a, b; Reyes et al., 2019). To date, no review has gathered scientific evidence regarding the results of the Chilean Food Law on Labelling and Advertising of Food on the perception, purchase intention and consumption habits of the Chilean population.

Thus, the purpose of this scoping review was to summarise the general results of Chilean Food Law implementation to help to understand how this policy will change consumers' behaviour.

\section{Materials and methods}

The review was developed following the guidelines established by Preferred Reporting Items for Systematic Reviews and Meta-Analyses extension for Scoping Reviews (PRISMA$\mathrm{ScR}$ ) (Table S1). The end of the implementation of the law is recent. Thus, a scoping review was chosen because the purpose was to map the available evidence and to provide an overview of this topic. Besides that, scoping reviews are exploratory and descriptive in
The impact of Chilean Food Law

implementation

69

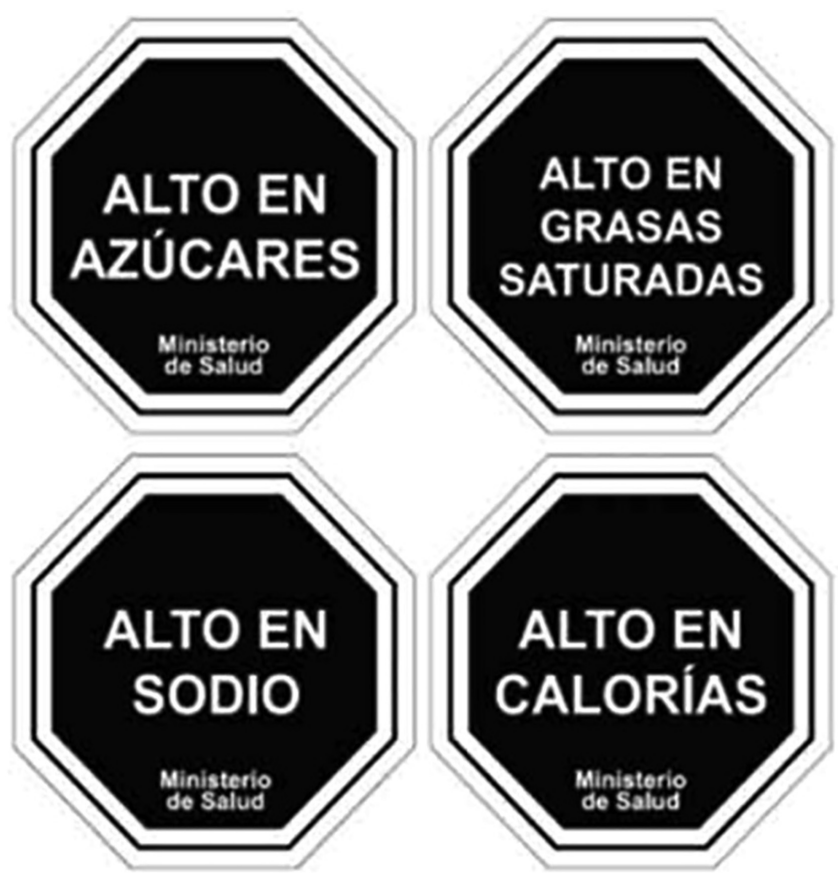

Figure 1.

Front warning seal models approved in Chile (Minsal, 2015) 
BFJ

124,13

nature, unlike systematic reviews that can be explanatory or analytical in nature (Peters $e t$ al., 2020).

The databases PubMed, Embase, Web of Science, Lilacs and Cochrane were used for the search process in all languages, during the period January 2015 to February 2020. The date of the last search was February 27, 2020.

To determine the search terms, after the researchers conducted previous tests and made the required adjustments, the following search strategies were used: "food labeling" and "advertising" and "Chile", "warning" and "food labelling" and "Chile", "Chilean law of food labelling", "nutritional information" and "Chile" and "consumer behaviour", "front-ofpackage nutrition label" and "Chile", and "food labelling" and "Chile" and "health".

The eligibility criteria included peer-reviewed journals; studies concerning the impacts of the first phase FOPWL implementation in Chile); and studies that investigated the Chilean population's perception, behaviour and purchasing habits.

Opinion articles, congress summaries, editorials, research not conducted in Chile and types of FOP other than the warning octagons implemented in Chile or conducted with nonpackaged food (e.g. food from restaurants and canteens), and studies conducted before the Chilean Food Law (CFL) were excluded. The CFL considered the warning labelling of foods rich in sugar, fat and sodium, as well their reduction in school environments and their restriction of marketing products that were child-directed. Thus, the selection of studies included all these aspects and their influence on perception, intention purchasing and consumption habits.

To select the articles, an independent reading was conducted by two researchers. In case of conflict, the decision was made by consensus. The first screening step consisted of reading the articles' titles and the selected articles were then evaluated through their abstract for eligibility. A full reading of the selected texts was performed to identify those that met established inclusion and exclusion criteria.

For each selected study, data extraction was performed by a single researcher, and this was subsequently checked and validated by the other involved parties. The following data were extracted: titles, authors, year of publication, study purposes, design, sample characteristics (size, age group, the ratio of each gender, sociodemographic level, study location and methodology used to obtain data), what results were measured and the possible study limitations pointed out by the authors themselves.

\section{Results}

Of 318 articles identified in the databases, 12 were selected for this scoping review. Figure 2 depicts the screening process summary.

The features of the studies included in the scoping review are presented in Table 1.

Among the selected studies, six addressed the impacts of CFL on children's eating habits, such as reducing their exposure to unhealthy foods through advertising restrictions and the prohibition of selling the food in schools.

For instance, two studies (Olivares-Cortés et al., 2017; Olivares et al., 2018), including 812 children from 3 private schools and 3 public schools located in Santiago, Chillán and Temuco cities investigated critical factors associated with the efficacy of the FOPWL strategy. Approximately, $87 \%$ of the children from a medium to high socioeconomic status (SES) and $78.5 \%$ from low SES indicated that they liked to be informed about the contents of food $(p<0.01)$. However, only $53 \%$ of the children from medium to high SES and $48 \%$ from low SES would stop buying foods associated with FOPWLs.

Additionally, $14 \%-22 \%$ of schoolchildren, independent of SES, would continue to consume sweet biscuits, sugary drinks, chocolates and chips with FOPWL (Olivares-Cortés et al., 2017). 


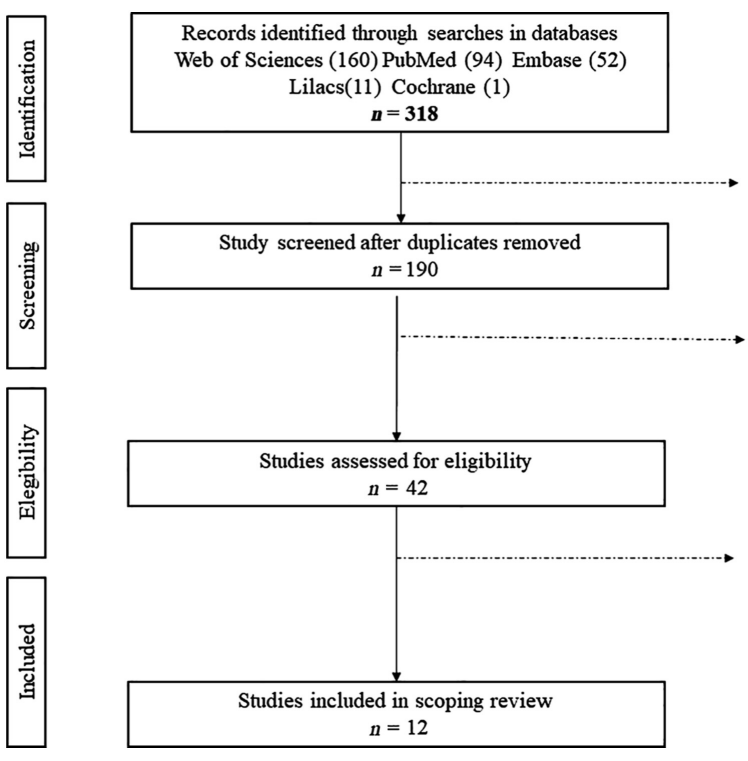

duplicates removed

$n=128$

studies excluded by

title/abstracts

$n=148$

studies excluded:

$n=30$

6 have not been conducted in chile

15 do not specifically address frontal nutrition labeling

4 prior to implementation of the new law

5 are not original articles about the new law implementation impacts

Figure 2. Study selection

\begin{tabular}{|c|c|c|c|}
\hline Reference & Subjects/Products $(n)$ & Time of investigation & \\
\hline $\begin{array}{l}\text { Olivares-Cortés } \\
\text { et al. (2017) }\end{array}$ & 812 school children $8-12$ years old & Second semester of 2016 & \\
\hline $\begin{array}{l}\text { Olivares et al. } \\
(2018)\end{array}$ & 812 school children $8-12$ years old & Second semester of 2016 & \\
\hline $\begin{array}{l}\text { Stoltze et al. } \\
\text { (2019) }\end{array}$ & $\begin{array}{l}168 \text { breakfast cereals packages from the } \\
\text { data collection in the year } 2015 \text { and } 146 \\
\text { packages from the year } 2016 \text { were included, } \\
\text { only with the Spanish language }\end{array}$ & $\begin{array}{l}\text { Before (February-March 2015) and after } \\
\text { (January-February 2017) the } \\
\text { implementation of the new law }\end{array}$ & \\
\hline $\begin{array}{l}\text { Correa et al. } \\
\text { (2019) }\end{array}$ & $\begin{array}{l}84 \text { mothers of children ( } 2-14 \text { years old) from } \\
9 \text { focus groups ( } 7-10 \text { people each) }\end{array}$ & July 2017 & \\
\hline $\begin{array}{l}\text { Massri et al. } \\
\text { (2019) }\end{array}$ & $\begin{array}{l}21 \text { schools and } 24 \text { school kiosks were } \\
\text { included }\end{array}$ & December 2014 and December 2016 & \\
\hline $\begin{array}{l}\text { Quitral et al. } \\
\text { (2019) }\end{array}$ & 100 products were evaluated & $\begin{array}{l}\text { Before the implementation of the new law } \\
\text { and October } 2017\end{array}$ & \\
\hline $\begin{array}{l}\text { Gregori et al. } \\
\text { (2019) }\end{array}$ & 167 adults were interviewed & $\begin{array}{l}\text { Before (September-October 2012) and after } \\
\text { (November-December 2016) the new law } \\
\text { implementation }\end{array}$ & \\
\hline $\begin{array}{l}\text { Schnettler et al. } \\
\text { (2019a) }\end{array}$ & $\begin{array}{l}494 \text { adults were interviewed. } 249 \text { evaluated } \\
\text { purchase intention and } 245 \text { evaluated } \\
\text { perceived healthfulness }\end{array}$ & August-October 2017 & \\
\hline $\begin{array}{l}\text { Schnettler et al. } \\
\text { (2019b) }\end{array}$ & 548 adults were interviewed & August-October 2017 & \\
\hline $\begin{array}{l}\text { Agúero et al. } \\
\text { (2020a) }\end{array}$ & 2331 adults were interviewed & February-March 2017 & $\begin{array}{r}\text { Table } \mathbf{1} \\
\text { Description of studies }\end{array}$ \\
\hline Agúero (2020b) & 4807 adults were interviewed & Not mentioned & that evaluated impact \\
\hline $\begin{array}{l}\text { Taillie et al. } \\
\text { (2020) }\end{array}$ & $\begin{array}{l}2383 \text { urban-dwelling households were } \\
\text { included }\end{array}$ & January 1, 2015 to December 31, 2017 & $\begin{array}{l}\text { of FOP implementation } \\
\text { on Chilean population }\end{array}$ \\
\hline
\end{tabular}


BFJ

124,13

Regarding electronic media for advertising, the data showed that TV continued to have a relevant place, with greater preference among those with low SES (50.6\%), versus $40.1 \%$ in those with high SES $(p<0.001)$. The Internet ranked second, with $38.2 \%$ preferences between those with high SES and $20.3 \%$ in low SES $(p<0.001)$, followed by cell phones, with $19.5 \%$ in those with high SES and $12.6 \%$ in low SES $(p<0.001)$. The favour advertisement was sugarsweetened beverages which reached $40.9 \%$ in those with high SES and $32.2 \%$ in those with low SES $(p<0.01)$. In total, $50 \%$ of the children with high SES and $44.1 \%$ with low SES stopped buying the foods with FOPWLs (Olivares et al., 2018).

In addition to the FOPWL, the CFL also includes a restriction on marketing for childdirected products rich in saturated fats, sugars, sodium or calories. In this sense, Stoltze et al. (2019), comparing the number of packages that used any kind of child-directed marketing strategy before and after the first CFL implementation phase, showed a significant decrease, from $36 \%$ before to $21 \%$ after $(\phi<0.05)$. The stratified investigation further showed that the decrease was mainly attributed to the lower number in the post-implementation sample of packages using strategies without characters. Furthermore, if the comparison was applied only to those food products classified as "high-in", then the observed decrease was even more prominent, going from $43 \%$ before the CFL implementations of packages with at least one child-directed marketing strategy prevalence to $15 \%$ after $(\phi<0.05)$; and from $36 \%$ packages using characters before to $15 \%$ after implementation $(p<0.05)$. Additionally, the use of noncharacter strategies among the so-called "high in" food products decreased significantly from $23 \%$ to $0 \%$ at post-implementation $(p<0.05)$. On the other hand, among the food products classified as "non-high-in", there was a significant increase in percentage for packages presenting a child-directed marketing strategy from $8 \%$ to $30 \%$ post-implementation $(p<0.05)$. This research did not evaluate children's intentions to purchase.

In addition, studies about mothers' perceptions and behaviour associated with the law were included in this review. The results showed that mothers were aware that higher numbers of warnings indicate unhealthier food products, and they classified FOPWL as useful, especially when purchasing new products. Moreover, mothers perceived that school environments are crucial to obesity prevention and have become healthier due to the implementation of the CFL. Other aspects of the CFL impact on food marketing restrictions, however, are rarely noticed by mothers. According to a study by Correa et al. (2019), an interesting asset of the regulatory effort is that young children, particularly those from lower and middle SESs, disseminate better dietary habits within their communities after schools make environmental changes.

Using gradual cut-off, the availability of food products (both solids and liquids) exceeding any cut-off in schools decreased from $90.4 \%$ in 2014 to $15.0 \%$ in 2016 (JUNAEB, 2019). For solid products, the availability of products exceeding any cut-off in schools went from $97 \%$ in 2014 to $14 \%$ in 2016, whereas liquid products went from $75.8 \%$ in 2014 to $14.3 \%$ in 2016 . Overall, a $5.1 \%$ reduction in the total number of items available was observed. In 2014, bakery products, candy and drinks were the most common food categories and accounted for $87.3 \%$ of food products. In 2016, the availability of bakery products decreased substantially, whereas drinks, cereals, ice cream, and milk and dairy products were available more frequently. The proportion of fruits and vegetables available in schools increased from 0.7 to $3.2 \%$ between 2014 and 2016 (Massri et al., 2019).

Only one study evaluated the reformulation of food for children after the implementation of the law. The results indicated that the formulations of products marketed in 2017 were modified by decreasing the concentration of sugar through the incorporation of noncaloric sweeteners (Quitral et al., 2019).

Six studies were conducted with the adult population. The main issues raised were the stage of consumers' purchase intention and perceived healthfulness with FOPWL and with different types of food product reformulations. 
The results showed that, in comparison to 2012, a higher proportion of subjects in 2016 reported being on a weight control program ( $47 \%$ in 2012 vs. $79 \%$ in $2016, p=0.011$ ) and saw FOPWL as the most efficient strategy introduced in Chile to stimulate healthy food choices (from 10\% in 2012 to $35 \%$ in 2016, $p<0.05$ ) (Gregori et al., 2019).

Concerning understanding, a high number of consumers stated that they read and understood the FOPWL both in 2012 and in 2016 (without a significant difference). However, only $6 \%$ of subjects in 2012 and $10 \%$ in 2016 stated that they knew what the guideline daily amount-GDA -was about. The ratio of the proper definition of nutrients "per $100 \mathrm{~g}$ ", "per serving" and "per $100 \mathrm{kcal}$ " remained the same between 2012 and 2016. The disposition to pay an additional tax for a more detailed FOPNL decreased between 2012 and 2016 (without a significant difference) (Gregori et al., 2019).

Two studies evaluated the consumers' behaviour change stage during the first phase of the CFL implementation (Agúero et al., 2020a, b). In these studies, the authors used Prochaska's stage model of behaviour, adapted by the American College of Sports Medicine, considering that the persons could be in one of the following phases: (1) precontemplation: there is no interest in adopting a certain habit, (2) contemplation: expressed interest in changing the behaviour and adopting the habit but not in the next six months, (3) preparation for action: there is interest in adopting a habit within the next 30 days and incorporating certain habits/actions leading to behaviour change, 4) action: adoption of a behaviour less than 6 months ago, and 5) maintenance: the maintenance of the behaviour for more than 6 months. More than $90 \%$ of the respondents referred to being aware of the law. However, more than $50 \%$ of the participants were in the precontemplation phase. Of this percentage, the food group that presented higher resistance to behaviour change was that of the breakfast cereals $(66.6 \%)$. Among the investigated foods, sweet beverages presented lower resistance to habit change, showing the lowest value in the precontemplation phase $(43.4 \%)$ and higher values in the preparation for action (18\%) and action (2.5\%) phases (Agúero et al., 2020a).

These findings were similar to those obtained during a study with 4,807 university students. Although most of the participants (99.3\%) stated they knew and understood the regulation, they were classified in the precontemplation phase concerning the importance of stopping the consumption of certain foods and how assured they were to make such a change (Agúero et al., 2020b).

The purchase of beverages with the FOPWL "high in sugar" showed a reduction of $23.7 \%$ volume in urban homes, independent of education level (Taillie et al., 2020a, b), confirming the data previously presented.

Two selected studies evaluated the impact of the reformulation of frankfurters, a product that is significantly consumed by the Chilean population, on consumers' healthfulness perception (Schnettler et al., 2019a,b). The results showed that the consumers perceived the artisanal brand as being healthier $(\phi<0.001)$. Additionally, the reformulation of products by decreasing sodium and fat, with no FOPWL once the content of sodium and fat did not reach the limits for their inclusion, caused a similar increase in health perception $(p<0.001)$. Frankfurter consumers noticed the reduction of sodium and fat by the absence of FOPWL as being healthier than those that had only one nutrient reduced (i.e. with just one nutritional warning) or the original version of the product (Schnettler et al., 2019a).

The reformulation also impacted purchase intention. Frankfurters with decreased sodium and fat in their composition were classified with the highest purchase intention (according to a nine-point hypothetical scale), followed by frankfurters with the reduction of only one critical nutrient (fat or sodium) and the original formulation. For brand type, the artisanal brand scored higher for the hypothetical purchase intention scale than the industrial brand (Schnettler et al., 2019a).

Other nutrients such as fibre and cholesterol produced only small changes in consumers' perception and purchase intention. A frankfurter reformulation higher in fibre was perceived 
BFJ

124,13

as healthier $(p<0.001)$ and caused an increase in the purchase intention of frankfurters $(p=0.022)$, while a packaging claim regarding cholesterol reduction did not affect the frankfurters overall, except for a minor effect observed for the purchase intention of the industrial brand only (Schnettler et al., 2019a). These results were similar to those obtained by a second frankfurters study $(n=548)$, where it was confirmed that consumers pay more attention to key nutrients, such as sodium and fat, while nutrients that are not mentioned in the CFL such as fibres and cholesterol do not raise much concern or health perception. However, despite the contribution of product reformulation to reducing the number of FOPWL, studies indicate that consumers are not open to paying more for such changes (Schnettler et al., 2019b).

\section{Discussion}

This is the first study, to our knowledge, that gathered all the research available in international databases and that evaluated the effects of the Chilean Law on the Labelling and Advertising of Food implementation on the perception, purchase intention, reformulation, and consumption habits of the Chilean population of both adults and children. This scoping review showed that consumers supported the implementation of the FOPWL and thought that it is a good strategy to help make healthier food choices for themselves. However, even with a positive perception about these products, the intention-tochange the purchase of unhealthy food occurred only for sugar-sweetened beverages.

Regarding children, it was also shown that they would not stop eating foods with a FOPWL, although the mothers' perception was that the presence of FOPWLs was important in differentiating unhealthy from healthy products. Law compliance in schools was evidenced by a decrease in the availability of products with FOPWLs. The child-directed marketing strategy showed a reduction after the first phase of implementation.

Chile was the first country to adopt mandatory FOPWL, and the government's expectation was that obesity numbers for both adults and children could decrease by the reduction of consumption of products labelled as "high in". Five months after the beginning of the first implementation phase of the CFL, the Chilean Ministry of Health surveyed 1,067 individuals of 18 years of age or older from Greater Santiago, including both genders and all socioeconomic levels to describe consumers' perceptions and attitudes concerning the law. Data showed that when visualising a product with one or more FOPWL, $78.5 \%$ of the respondents indicated that the labelling would affect their purchase decision, including the reduction of the consumed amounts $(26.6 \%)$, decrease in consumption frequency $(26.2 \%)$ or interruption of consumption (25.7\%) (MINSAL, 2017).

In this scoping review, sugar-sweetened beverages (SSBs) were the most reformulated product, and their original formulation (with FOPWL) presented the highest reduction in purchases. Notwithstanding, our findings show that the consumers are not willing to pay more for such changes. Therefore, the data showed that consumers are ready to choose products reformulated without FOPWLs when the price remains unchanged.

Regarding the understanding of consumer behaviour, this is a complex matter. The articles included in this review pointed to an increase in health perception after the reformulations of products and are according to Plasek et al. (2020), who pointed out that a reduction in the content of critical nutrients such as sodium, sugar and fat seems to increase consumer acceptance. However, later studies pointed toward a selective reduction in consumption that was not equal among food categories. Barahona et al. (2020) investigated the mechanism behind the choice of consumers regarding breakfast cereal. The authors concluded that the products that were perceived as healthy but received labels experienced the largest decline in demand. However, this reduction was not equal among the categories showing that only when the product gives new information to consumers can the behaviour 
change. These data are similar to those reported by Araya et al. (2021), who analysed purchase estimative data from 2016 and observed a decline in labelled breakfast cereal and that consumers are not inclined to replace chocolate and cookies with warning labels. This indicated that FOWPL does not change behaviour unless new information is presented about the nutritional content. Foods already "high in" before the law are still consumed after implementation.

One of the law's expectations is the reduction of obesity rates in the Chilean population, both in children and adults. Research has shown that reducing calorie consumption by consuming products without FOPWLs may have positive results in the future. Basto-Abreu et al. (2020), through a mathematical model, estimated that the introduction of warning labels in Mexico could lead to a reduction in caloric intake and, consequently, to an estimated reduction of $14.7 \%$ in the prevalence of obesity, after 5 years, among adults under 60 . This represents an estimated savings of US $\$ 1.8 \mathrm{bn}$ in obesity costs.

These data align with those reported by Taillie et al. (2021), who estimated the percentage of nutrient content in packaged products purchased after the implementation of the CFL. The products indicated that overall purchases declined by $16.4 \mathrm{kcal} / \mathrm{capita} /$ day $(95 \% \mathrm{CI}-27 \cdot 3$ to $-5 \cdot 6 ; p=0.0031)$ or $3.5 \%$ in calories, $11.5 \mathrm{kcal} / \mathrm{capita} /$ day $(-14.6$ to $-8 \cdot 4 ; p<0.0001)$ or $10.2 \%$ in sugar, $2.2 \mathrm{kcal} /$ capita/day $(-3.8$ to $-0.5 ; p=0.0097)$ or $3.9 \%$ in saturated fat and $27.7 \mathrm{mg} / \mathrm{capita} /$ day $(-46.3$ to $-9.1 ; p=0.0035)$ or $4.7 \%$ in sodium. However, the aforementioned study included only regular products. In the future, it will be important to evaluate other types of food consumed, such as those consumed away from home or in bulk, that contribute to caloric intake.

Although these findings estimate a change in purchases, in Chile, there are only results about the first phase of implementation, and there is no correlation between the results and the prevalence of obesity yet. Thus, in the future, new studies carried out after the third phase will be useful.

Regarding the productive sector, the response was positive after implementation of the law through the reformulation of several food products. A dataset with Chilean packaged food and beverage nutritional composition was developed through the collection of information during two time periods: before (T0: January-February 2015 or 2016; $n=4,055)$ and after (T1: January-February $2017 ; n=3,025)$ CFL implementation. Food products that receive the "high in sugar" warning went from $80 \%$ to $60 \%$ in proportion, the "high in sodium" category registered a reduction from 74 to $27 \%$ in proportion and the proportion of food products that fit into the "high in saturated fats" and "high in energy" category decreased for savoury spreads only and breakfast cereals and savoury spreads, respectively (Reyes et al., 2020).

Corvalán et al. (2021) verified 1,915 foods in 16 product categories comparing the nutritional information of products considered "high-in" before the implementation of the law (2015-2016) and after its implementation (2017), to detect the proportion of products reformulated. It was shown that $15 \%$ of this total was reformulated, and the changes were statistically significant mainly regarding the reduction of sugar (beverages, milk and dairy products, breakfast cereals, desserts and ice cream and sweet pastes) and sodium (salty paste, cheeses and cured meats).

Sambra et al. collected ingredient information on 19 supermarkets and 13 food web pages from December 2018 to October 2019 to highlight the overuse of noncaloric sweeteners in Chile after the first CFL implementation phase. Among the 1,489 foods included, 815 (55.5\%) presented at least one noncaloric sweetener (NCS) in their composition. Stratifying by food group, the authors reported that $31.5 \%$ of cereal products, $67.1 \%$ of dairy products, $74.3 \%$ of non-alcoholic beverages, $46.2 \%$ of sweets and other desserts, and $49 \%$ of processed fruits contained NCS (Sambra et al., 2020).

Although these initial results are positive, there are two main concerns about the next steps. It is necessary to investigate whether reformulation occurs only in categories of 
BFJ

124,13

products that are easier to reformulate and if they will have the same price after reformulation. This includes beverages and breakfast cereal. Also important is how this may affect different socioeconomic segments of the population and if these reformulated products are sufficient to reduce the prevalence of obesity.

To further protect children, the CFL also included restrictions to child-directed marketing strategies for all regulated foods and promoted healthier school environments. In the current study, television (TV) was the main electronic advertising media for children. Examining the role of TV food advertising regulation on the consumption of food containing FOPWL by children, a recent study revealed a decline in children's food choice and TV advertising exposure from 2016 to $2017(p<0.01)$ (Jensen et al., 2021). According to the study, the decreased consumption of food containing FOPWL did not occur due to changes in advertising exposure. These results led to the conclusion that other components of CFL must be involved to reduce the consumption of unhealthy food; in other words, a reduction in the consumption of TV ads alone is not sufficient (Jensen et al., 2021). Thus, more studies are necessary to define which aspect of the law contributed more to changes in the food environment and behaviour.

The authors of the included studies mentioned limitations in their studies, such as crosssectional design, which precludes causal assumptions and small sample sizes. Careful generalisation must be made based on the data presented here and most of the studies were not designed to reflect the usual dietary habits of the Chilean population. Furthermore, there is a limitation regarding the diversity of the investigated products (specific items such as SSBs and frankfurters), as well as the place where the studies were conducted, which did not include all the country regions.

This scoping review is important because it provides an overview of the evidence available to date on the effect of this policy on the behaviour of Chilean consumers, where Chile is the country that has implemented this FOPWL model for the longest time. Among the selected studies, $100 \%$ had their data collected before the start of the second phase of CFL implementation (June 2018), so it is expected that the perception and intention data will effectively translate into reduced purchasing and consumption of products with high content of critical nutrients. This can influence the reduction of obesity and associated diseases after the law is completely implemented.

However, given the long-term, complex and multidimensional nature of obesity, and the long-term evaluation of Chilean population data because there is no control group, such as a randomised controlled trial, a longer period of observation will be necessary to detect the impact on obesity.

For now, there are still several pieces missing in this puzzle. The monitoring of this policy in Chile by policymakers and scientific institutions will be important to provide new clues on how to lead this change. In addition, giving subsidies to countries that have implemented similar practices to understand and anticipate other strategies in addition to food labelling may be adopted to reinforce healthy practices such as nutritional education programs and the encouragement of physical activity.

Regarding reformulation, it is important that in addition to the focus on reducing critical nutrients, there is opportunity to focus on other compounds such as fibre, omega- 3 and phytosterols that can also improve the nutritional profile of foods and that consumers be informed about the global importance of all nutrients to health.

\section{Conclusions}

Our results showed that in the first phase of CFL implementation, most of the adult and child consumers understood the purpose of FOPWL. However, the consumer continued to purchase the products even with FOPWL except for SSBs, indicating that a FOPWL impacts product 
categories differently. Thus, further research is required to investigate whether such behaviour was maintained after the implementation of the CFL following phases and which tools can be used to guide changes in consumer behaviour regarding other product categories.

This information is essential to understand the effect of FOPWL as a policy intended to change people's behaviour, and to guide further adaptations or additional actions to the law not only in Chile but also in other countries willing to apply similar legal tools to decrease unhealthy food consumption in their population.

We believe that health policies should not be focused only on the nutritional labelling of packaged products but should also be a set of actions that provide better food choices in general. As obesity is considered to have a multifactorial cause, diversified actions must also be considered.

\section{References}

Agência Nacional de Vigilância Sanitária - ANVISA (2018), "Relatório Preliminar de Análise de Impacto Regulatório sobre Rotulagem Nutricional", available at: http://antigo.anvisa.gov.br/documents/ 33880/2977862/An \% C3\% A1lise+de+Impacto+Regulat \% C3\% B3rio+sobre+Rotulagem +Nutricional_vers\%C3\%A3o+final+3.pdf/2c094688-aeee-441d-a7f1-218336995337 (accessed 30 Setempber 2021).

Agencia Nacional de Vigilancia Sanitaria - ANVISA (2020), "Resolução da Diretoria Colegiada RDC n²29, de 8 de outubro de 2020", available at: http:/antigo.anvisa.gov.br/documents/ 10181/3882585/RDC_429_2020_.pdf/9dc15f3a-db4c-4d3f-90d8-ef4b80537380 (accessed January 2021).

Agüero, S.D., Araneda, J., Ahumada, D., Silva Rojas, J.S., Bonacich, R.B., Caichac, A., Salamanca, M.F., Villarroel, P., Fernandez, E., Pacheco, V., Martinovic, P.A., Wilson, W., Neira, A.M., Encina, C. and Moya Tillería, J.M. (2020a), "A multicenter study evaluating the stages of change in food consumption with warning labels among Chilean university students", BioMed Research International, Vol. 2020, 2317929.

Aguero, S.D., Ocampo, P.S., Sanchez, J.G., Sanchez, Y.F. and Tillería, J.M. (2020b), "Stages of change in the purchase of packaged foods after phase 1 of the implementation of the new food policy in Chile 2017”, Nutrition, Vol. 71 No. 110593, pp. 1-5.

Araya, S., Elberg, A., Noton, C. and Schwartz, D. (2021), "Identifying food labeling effects on consumer behavior”, available at: https://papers.ssrn.com/sol3/papers.cfm?abstract_id=3195500 (accessed 30 Setempber 2021).

Barahona, N., Otero, C., Otero, S. and Kim, J. (2020), "Equilibrium effects of food labeling policies”. doi: 10.2139/ssrn.3698473 (accessed 30 Setempber 2021).

Basto-Abreu, A., Torres-Alvarez, R., Reyes-Sánchez, F., González-Morales, R., Canto-Osorio, F., Colchero, M.A., Barquera, S., Rivera, J.A. and Barrientos-Gutierrez, T. (2020), "Predicting obesity reduction after implementing warning labels in Mexico: a modeling study", PLoS Medicine, Vol. 17 No. 7, e1003221.

Comisión Federal para la Protección Contra Riesgos Sanitarios (COFEPRIS), México (2010), "Modificación a la Norma Oficial Mexicana NOM-051-SCFI/SSA1-2010, Especificaciones generales de etiquetado para alimentos y bebidas no alcohólicas preenvasados-Información comercial y sanitaria”, available at: https://www.dof.gob.mx/2020/SEECO/NOM_051.pdf (accessed September 2020).

Correa, T., Fierro, C., Reyes, M., Carpentier, F.R.D., Taillie, L.S. and Corvalan, C. (2019), "Responses to the Chilean law of food labeling and advertising: exploring knowledge, perceptions and behaviors of mothers of young children", International Journal of Behavioral Nutrition and Physical Activity, Vol. 16 No. 1, pp. 1-10.

Corvalán, C., Correa, T., Reyes, M. and Paraje, G. (2021), Impacto de la ley chilena de etiquetado en el sector productivo alimentario, FAO e INTA, Santiago de Chile, p. 86, ISBN: 978-92-5-133958-9, doi: 10.4060/cb3298es (accessed 30 Setempber 2021).
The impact of Chilean Food Law implementation 
BFJ

124,13

Corvalán, C., Reyes, M., Garmendia, M.L. and Uauy, R. (2018), "Structural responses to the obesity and non-communicable diseases epidemic: update on the Chilean law of food labelling and advertising", Obesity Reviews, Vol. 20 No. 3, pp. 367-374.

Endalifer, M.L. and Diress, G. (2020), "Epidemiology, predisposing factors, biomarkers, and prevention mechanism of obesity: a systematic review", Journal of Obesity, Vol. 2020, pp. 1-8.

Food and Agriculture Organization of the United Nations - FAO (2016), "Handbook on food labelling to protect consumers", available at: http://www.fao.org/3/a-i6575e.pdf (accessed September 2020).

Gregori, D., Azzolina, D., Lanera, C., Ghidina, M., Gafare, C.H. and Lorenzoni, G. (2019), "Consumers attitudes before and after the introduction of the Chilean regulation on food labelling", International Journal of Food Sciences and Nutrition, Vol. 70 No. 7, pp. 868-874.

INVIMA (Instituto Nacional de Vigilância de Medicamentos e Alimentos) (2021), "RESOLUCIÓN 810 DE 2021: reglamento técnico sobre los requisitos de etiquetado nutricional y frontal que deben cumplir los alimentos envasados o empacados para consumo humano", available at: https:// normograma.invima.gov.co/docs/resolucion_minsaludps_0810_2021.htm (acessed 30 September 2021).

Jensen, M.L., Carpentier, F.D., Adair, L., Corvalán, C., Popkin, B.M. and Taillie, L.S. (2021), "Examining Chile's unique food marketing policy: TV advertising and dietary intake in preschool children, a pre- and post- policy study", Pediatric Obesity, Vol. 16 No. 4, pp. 1-11, e12735.

JUNAEB, Junta Nacional de Auxilio Escolar y BecasNutricional (2019), "Mapa (2019), Mapa Nutricional 2019 de la Junta Nacional de Auxilio Escolar y Becas (Junaeb)", available at: https:// www.junaeb.cl/wp-content/uploads/2013/03/Mapa-Nutricional-2019-1.pdf (accessed 30 September 2021).

Kanter, R., Vanderlee, L. and Vandevijvere, S. (2018), "Front-of-package nutrition labelling policy: global progress and future directions", Public Health Nutrition, Vol. 21 No. 8, pp. 1399-1408.

(MINSAL) Ministerio de Salud (2017), "Encuesta nacional de Salud 2016-2017: primeros resultados", available at: https://www.minsal.cl/wp-content/uploads/2017/11/ENS-2016-17_PRIMEROSRESULTADOS.pdf (accessed September 2020).

(MINSAL) Ministerio de Salud (2019), "Hoja informativa evaluación ley de Alimentos 20.206", available at: https://www.minsal.cl/wp-content/uploads/2019/08/EVALUACION-LEY-DEALIMENTOS_julio-2019_02.pdf (accessed September 2020).

Massri, C., Sutherland, S., Källestål, C. and Peña, S. (2019), "Impact of the food-labeling and advertising law banning competitive food and beverages in Chilean public schools, 2014-2016", American Journal of Public Health, Vol. 109 No. 9, pp. 1249-1254.

Ministerio de Salud - MINSA, Gobierno del Perú (2018), "Decreto Supremo No 012-2018-AS. 21 de junio de 2018", available at: https://www.gob.pe/institucion/produce/normas-legales/185544-0122018-sa (accessed September 2020).

MINSAL (Ministerio de la Salud) (2015), Sello frontal de advertencia en etiquetas de los alimentos envasados. Diario Oficial de la República de Chile. 26 de junio de 2015, Modifica Decreto Supremo No 977.1996. Reglamento Sanitario de los Alimentos. Decreto 13, available at: https:// www.minsal.cl/wp content/uploads/2015/08/decreto_etiquetado_alimentos_2015.pdf (acessed 30 September 2021).

Olivares, S., Araneda, J., Morales, G., Leyton Dinamarca, B. and Oyarzún, M.T (2018), "Percepción de escolares chilenos de distinto nivel socioeconómico sobre la regulación de la publicidad de alimentos", Revista de la Sociedad Latinoamericana de Nutrición, Vol. 68 No. 1, pp. 88-94.

Olivares-Cortés, S., Araneda-Flores, J., Morales-Illanes, G., Leyton-Dinamarca, B., Bustos-Zapata, N., Hernández-Moreno, M.A. and Oyarzún-Macchiavello, M.T. (2017), "Actitudes de escolares chilenos de distinto nivel socioeconómico al inicio de la implementación de la ley que regula la venta y publicidad de alimentos altos en nutrientes críticos", Nutrición Hospitalaria, Vol. 34 No. 2, pp. 431-438. 
Pagliai, G., Dinu, M., Madarena, M., Bonaccio, M., Iacoviello, L. and Sofi, F. (2021), "Consumption of ultra-processed foods and health status: a systematic review and meta-analysis", British Journal of Nutrition, Vol. 125 No. 3, pp. 308-318, doi: 10.1017/S0007114520002688.

Peters, M.D.J., Casey, M., Tricco, A.C., Pollock, D., Munn, Z., Alexander, L., Mclnerney, P., Godfrey, C.M. and Khalil, H. (2020), "Updated methodological guidance for the conduct of scoping reviews", JBI Evidence Synthesis, Vol. 18 No. 10, pp. 2119-2126.

Plasek, B., Lakner, Z. and Temesi, Á. (2020), "Factors that influence the perceived healthiness of foodreview", Nutrients, Vol. 12 No. 6, 1881, pp. 1-20.

Quitral, V., Arteaga, J., Rivera, M., Galleguillos, J. and Valdés, I. (2019), “Comparación del contenido de azúcares y edulcorantes no calóricos en néctares y bebidas antes y después de implementar la ley chilena 20.606”, Revista chilena de nutrición, Vol. 46 No. 3, pp. 245-253.

Reyes, M., Garmendia, M.L., Olivares, S., Aqueveque, C., Zacarías, I. and Corvalán, C. (2019), "Development of the Chilean front-of-package food warning label", BMC Public Health, Vol. 19 No. 1, pp. 1-11.

Reyes, M., Taillie, L.S., Popkin, B., Kanter, R., Vandevijvere, S. and Corvalán, C. (2020), "Changes in the amount of nutrient of packaged foods and beverages after the initial implementation of the Chilean Law of Food Labelling and Advertising: a nonexperimental prospective study", PLoS Med, Vol. 17 No. 7, pp. 1-37, e1003220.

Sambra, V., López-Arana, S., Cáceres, P., Abrigo, K., Collinao, J, Espinoza, A., Valenzuela, S., Carvajal, B., Prado, G., Peralta, R. and Gotteland, M. (2020), "Overuse of non-caloric sweeteners in foods and beverages in Chile: a threat to consumers' free choice?", Frontiers in Nutrition, Vol. 7 No. 68, pp. 1-8.

Schnettler, B., Ares, G., Sepúlveda, N., Bravo, S., Villalobos, B., Hueche, C. and Lobos, G. (2019a), “Are consumers willing to pay more for reformulated processed meat products in the context of the implementation of nutritional warnings? Case study with frankfurters in Chile", Meat Science, Vol. 152, pp. 104-108.

Schnettler, B., Ares, G., Sepúlveda, N., Bravo, S., Villalobos, B., Hueche, C. and Adasme-Berríos, C. (2019b), "How do consumers perceive reformulated foods after the implementation of nutritional warnings? Case study with frankfurters in Chile", Food Quality and Preference, Vol. 74, pp. 179-188.

Stoltze, F.M., Barker, J.O., Kanter, R., Corvalán, C., Reys, M., Taillie, L.S. and Carpentier, F.R.D. (2019), "Prevalence of child-directed marketing on breakfast cereal packages before and after Chile's Food Marketing Law: a pre-and post-quantitative content analysis", International Journal of Environmental Research and Public Health, Vol. 16 No. 22, 4501, pp. 1-15.

Storcksdieck Genannt Bonsmann, S., Marandola, G., Ciriolo, E., Van Bavel, R. and Wollgast, J. (2020), Front-of-pack Nutrition Labelling Schemes: A Comprehensive Review, Publications Office of the European Union, available at: https://publications.jrc.ec.europa.eu/repository/bitstream/ JRC113586/kjna29811enn_1.pdf (accessed September 2021).

Taillie, L.S., Reyes, M.M., Colchero, M.A., Popkin, B. and Corvalan, C. (2020a), “An evaluation of Chile's Law of Food Labeling and Advertising on sugar-sweetened beverage purchases from 2015 to 2017: a before-and-after study", PLoS Medicine, Vol. 17 No. 2, pp. 1-22, e1003015.

Taillie, L.S., Hall, M.G., Popkin, B.M., Ng, S.W. and Murukutla, N. (2020b), "Experimental studies of front-of-package nutrient warning labels on sugar-sweetened beverages and ultra-processed foods: a scoping review", Nutrients, Vol. 12 No. 569, pp. 1-24.

Taillie, L.S., Bercholz, M., Popkin, B., Reys, M., Colchero, M.A. and Corvalán, C. (2021), "Changes in food purchases after the Chilean policies on food labelling, marketing, and sales in schools: a before and after study", The Lancet Planetary Health, Vol. 5 No. 8, pp. 526-e533.

Talati, Z., Egnell, M., Hercberg, S., Julia, C. and Pettigrew, S. (2019), “Consumers' perceptions of five front-of-package nutrition labels: an experimental study across 12 countries", Nutrients, Vol. 11 No. 8, pp. 1-15.

The impact of Chilean Food Law implementation 
BFJ

124,13

80

\section{Appendix}

The supplementary files are available online for this article.

\section{About the authors}

Cintia Pereira da Silva is a nutritionist, $\mathrm{PhD}$, expertise in food science and technology with emphasis on the following topics: development of products with functional properties, sensorial analysis, identification of bioactive compounds present in natives raw materials by molecular biology assays. Currently, a postdoctoral researcher at Department of Nutrition, School of Public Health, University of São Paulo, São Paulo, Brazil.

Aline Cristina Bento is a nutritionist, expertise in food health surveillance, quality management and food safety and multidisciplinary approach of obesity and exercise physiology. Aline Cristina Bento has professional experience in regulatory affairs, quality and food safety. Currently, professor at Instituto Racine.

Elaine Guaraldo is a nutritionist, master in food and nutrition (UNICAMP). Elaine Guaraldo has professional experience in food science, food labelling and food regulation. Currently, Elaine Guaraldo is professor at Universidade Municipal de São Caetano do Sul and at Instituto Racine; and founder and director of Vigna Brasil Consultoria em Assuntos Estratégicos e Regulatórios. Elaine Guaraldo is also a health division regulatory manager. Elaine Guaraldo is the corresponding author and can be contacted at: elaine@vignabrasil.com.br

For instructions on how to order reprints of this article, please visit our website: www.emeraldgrouppublishing.com/licensing/reprints.htm Or contact us for further details: permissions@emeraldinsight.com 